\title{
THE TOF-GUARD NEUROMUSCULAR TRANSMISSION MONITOR AND ITS USE IN HORSES ${ }^{1}$
}

\author{
O MONITOR DA TRANSMISSÃO NEUROMUSCULAR \\ "TOF-GUARD" E SEU USO EM EQÜINOS
}

\author{
Juliana Noda Bechara ${ }^{2}$ Denise Tabacchi Fantoni ${ }^{3}$ Paulo Sergio de Moraes Barros $^{4}$ \\ Elton Rodrigues Migliati ${ }^{5}$ Marcio Augusto Ferreira $^{6}$ \\ Luis Claudio Lopes Correia da Silva ${ }^{7}$
}

SUMMARY

It has been emphasized in the human medical literature, that when using a neuromuscular blocking agent, it is of vital importance the monitoring of the neuromuscular block and that these agents should never be used without it. The purpose of this study was to evaluate the use of the neuromuscular transmission monitor TOF-Guard in horses. Twelve horses were randomly assigned whether to receive pancuronium or atracurium as the neuromuscular blocking agent. All horses were pre-medicated with romifidine, anaesthesia induced with diazepam and ketamine and maintenance with halothane. Abolition of spontaneous ventilation was accomplished by the administration of atracurium or pancuronium. The time from injection of the muscle relaxant agent to the onset of maximum block $(T 1=0)$, recovery of $T 1$ to $25 \%$ and the recovery of TOF ratio to 0.7 were recorded, as was the time for recovery of $T 1$ from 25 to $75 \%$. It was concluded that it is very important the neuromuscular transmission monitoring during the use of a nondepolarizing neuromuscular blocking agent, since it provides a safer anaesthetic and surgical procedure with the use of adequate dosages and due to the impossibility of a superficialization of the neuromuscular blockade during a surgical procedure. The TOF-Guard showed to be a good option for neuromuscular monitoring in horses.

Key words: neuromuscular blocking agents, neuromuscular transmission monitor, TOF-Guard, horses.
Quando da utilização de bloqueadores neuromusculares, já foi enfatizado na literatura médica humana, que é de vital imporância a monitoração do bloqueio neuromuscular e que estes agentes nunca devem ser utilizados sem a mesma. O objetivo deste estudo foi o de avaliar o uso do monitor da transmissão neuromuscular TOF-Guard em eqüinos. Para tanto, doze eqüinos foram separados aleatoriamente para receberem como bloqueadores neuromusculares o pancurônio ou o atracúrio. Todos os eqüinos foram pré-medicados com romifidina, induzidos com diazepam e quetamina e mantidos com halotano. Foi administrado o atracúrio ou o pancurônio, seguindo-se a apnéia e início da ventilação mecânica controlada. O tempo entre a administração do relaxante muscular e a obtenção de um bloqueio máximo $(T 1=0)$, o retorno do $T 1$ para $25 \%$ e da razão do TOF para 0,7 e o tempo do retorno do T1 de 25 para $75 \%$ foram mensurados. Concluiu-se que é de grande importância a monitoração do bloqueio neuromuscular quando da utilização de um bloqueador neuromuscular nãodespolarizante, uma vez que ela torna o ato anestésico e cirúrgico mais seguro, com a utilização de doses adequadas que inviabilizam a superficialização do bloqueio durante o procedimento cirúrgico. O monitor TOF-Guard mostrou ser uma boa opção para a monitoração do bloqueio neuromuscular em eqüinos.

Palavras-chave: bloqueadores neuromusculares, monitor da transmissão neuromuscular, TOF-Guard, eqüinos.

INTRODUCTION

RESUMO

\footnotetext{
${ }^{1}$ Financial support: Fundação de Amparo à Pesquisa do Estado de São Paulo (FAPESP).

${ }^{2}$ Médico Veterinário, Pós-graduando, Faculdade de Ciências Agrárias e Veterinárias da UNESP, Campus de Jaboticabal, SP. Endereço: Rua Cabo Verde, 290/133, Vila Olímpia, 04550-081, São Paulo, SP. E-mail: bechara@ @cav.unesp.br. Autor para correspondência.

${ }_{3}^{3}$ Médico Veterinário, Professor Assistente, Doutor, Faculdade de Medicina Veterinária e Zootecnia (FMVZ), USP.

${ }^{4}$ Médico Veterinário, Professor Titular, FMVZ, USP.

${ }^{5}$ Médico Veterinário, F MV Z, USP.

${ }^{6}$ Médico Veterinário, Pós-graduando, FMVZ, USP.

${ }^{7}$ Médico Veterinário, Professor Assistente, FMVZ, USP. 


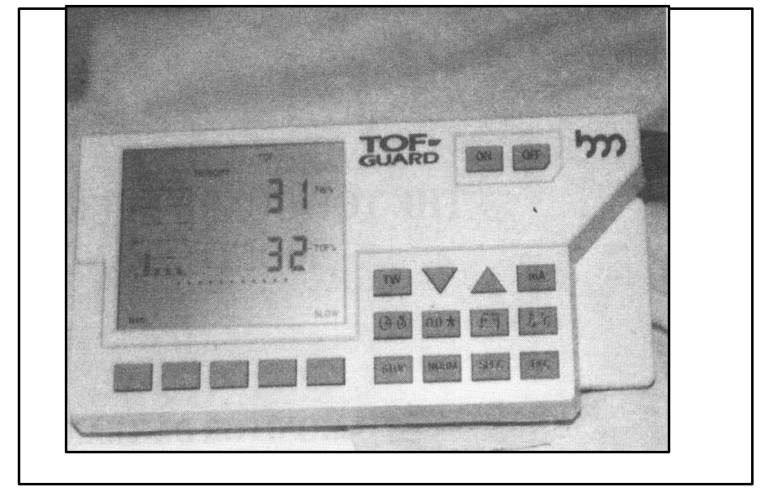

Figure 1 - The TOF-Guard monitor showing the percent twitch height (T1) and the train of four ratio which are continuously displayed

monitored whenever possible during the administration of muscle relaxants. Monitoring provides details about the quantity of neuromuscular blocker required to produce the desired muscle relaxation for surgery and when to administer an antagonist for blockade reversal. In addition it provides an indication of the muscle function present to permit spontaneous breathing and recovery. Neuromuscular actions of relaxants can be modified by numerous factors such as the presence of other drugs, electrolyte and acid-base disturbances, and ongoing pathologic processes. With monitoring of neuromuscular function during the administration of relaxants, more appropriate dosing can be achieved. When muscle relaxants are administered to human patients as part of the anaesthetic protocol, in the recovery stage from anaesthesia, muscle strength can be assessed by voluntary movements to command, a method not available in veterinary anaesthesia (CULLEN, 1996).

The generally accepted criteria describing onset and recovery of neuromuscular blockade have been established using mechanomyography in which a force transducer measures the response to nerve stimulation. However, it requires considerable time for setting up and stabilization, maintenance of a constant preload and fixed arm position. Simple tactile assessment of the train-of-four (TOF) responses is therefore often used to monitor neuromuscular block (LOAN et al., 1995). However, monitoring with simple nerve stimulators has been shown to be unreliable even in experienced hands and residual blockade has been observed despite their use (PEDERSEN et al., 1990; SHORTEN et al., 1992).
The TOF-Guard (Figure 1) is one of the latest developments in the field of neuromuscular monitoring equipment. This system uses a miniature acceleration transducer. The rationale behind the method is Newton's second law, stating that the acceleration is directly proportional to the force (UEDA et al., 1994). It combines advanced technology with the newest knowledge about data handling, stimulation patterns, necessary current, and significance of peripheral skin temperature for the response to nerve stimulation. The monitoring system consists of a stimulating and recording unit with a liquid crystal display, and a cable with four different sections: two stimulation electrode connections, one for the acceleration transducer, and one for a sensor for measuring skin temperature. The following stimulation patterns are optional: $1 \mathrm{~Hz}$ and $0.1 \mathrm{~Hz}$ single twitch stimulation, TOF stimulation every 12 seconds, TOF every 5 minutes (for use in the ICU), posttetanic count stimulation (PTC), and double burst stimulation. The chosen variables are constantly shown both numerically and graphically on the display. Other data, such as peripheral skin temperature, the battery charge, and the current delivered can be displayed on demand. The data are also stored on a memory card, and may latter be transferred to a computer (JENSEN et al., 1993).

Previous studies made in human medicine comparing the TOF-Guard with the Myograph 2000, showed that there is a very close positive correlation between the values of $\mathrm{T} 1$ (control twitch height), the TOF ratio and PTC, simultaneously measured by both methods (UEDA et al., 1994; MELLONI, 1995). However, other studies suggested that the TOF-Guard should not be used interchangeably with the Myograph because of a wide limit of agreement between the two monitors (MCCLUSKEY et al., 1997; LOAN et al., 1995)

Recent studies had been performed using the TOF-Guard to evaluate different nondepolarizing neuromuscular blocking agents in children (HODGES, 1996; ANSERMINO, 1996) and adults (JENSEN $\boldsymbol{e t}$ al., 1993; JAN $\boldsymbol{e t}$ al., 1996; HANS $\boldsymbol{e t}$ al., 1996; LLLWITZ et al., 1997; HANS et al., 1997).

In the anaesthetized laterally recumbent horse, the peroneal nerve is stimulated as it crosses the fibula shaft just distal to the head of the fibula (KLEIN et al., 1983). Alternatively, in the horse, the facial nerve, which is palpated subcutaneously over the masseter muscle ventral to the lateral canthus of the eye, can be stimulated in this region and the evoked muscle contractions of the muzzle recorded (BOWEN, 1969; JONES \& PRENTICE, 1976). The hoof twitch shows greater sensitivity to the effects of 
relaxants than the facial muscle twitch in horses and ponies given atracurium and pancuronium (MANLEY $\boldsymbol{e}$ t al., 1983; HILDEBRAND \& ARPIN, 1988; HILDEBRAND et al., 1989). For this reason the peroneal nerve is the best choice for neuromuscular monitoring in this specie.

Normally, the horse is observed in recovery from a neuromuscular blockade for signs of muscle weakness: inability to keep the eyelids closed tightly, inability to hold the head up, muscle fasciculation during attempts to stand (KLEIN, 1991). These are fine and subjective parameters that only by itself can mislead the anaesthesilogist and a re-curarization can occur despite these observations. In the present study, the use of the TOF-Guard for monitoring the neuromuscular blockade obtained with nondepolarizing muscle relaxants in horses, was evaluated.

\section{MATERIAL AND METHODS}

Twelve horses of different breeds and ages, weighting between 300 and $500 \mathrm{~kg}$ refereed to the University of São Paulo Veterinary Hospital were used. The horses underwent clinical examinations to rule out diseases that could interfere with the results. They were randomly assigned whether to receive pancuronium or atracurium as the neuromuscular blocking agent, and the anaesthesiologist in charge of recording the neuromuscular blockade did not know which drug was being used. Five horses received pancuronium and seven horses received atracurium as the neuromuscular blocking agent.

Horses were sedated with romifidine $(0.12 \mathrm{mg} / \mathrm{kg}, \mathrm{IV})$, before induction of anaesthesia. After 15 minutes they were anaesthetized with diazepam $^{\mathrm{i}}(0.05 \mathrm{mg} / \mathrm{kg}$, IV) and ketamine $(2.0 \mathrm{mg} / \mathrm{kg}, \mathrm{IV})$. The horses were positioned in lateral recumbency and endotracheal intubation was performed. Anaesthesia was maintained on a closed circle system of a large animal anaesthetic machine (Model 2800, Mallard Medical, Irvine, California) with halothane $\mathrm{i}^{\mathrm{ii}}$ in $100 \%$ of oxygen. Abolition of spontaneous ventilation was accomplished by the administration of atracurium $(0.1 \mathrm{mg} / \mathrm{kg}$, IV $)$ or pancuronium $^{\mathrm{f}}(0.1 \mathrm{mg} / \mathrm{kg}$, IV). Once apnea was established, controlled ventilation was started. Tidal volume employed was around $12 \mathrm{ml} / \mathrm{kg}$ and respiratory rate was adjusted to maintain a final end tidal carbon dioxide level no greater than $50 \mathrm{mmHg}$, I:E relation (1:2) was settled in the ventilation machine (Rachel, Model 2800, Mallard Medical, Irvine, California). At the end of the surgical procedure ( 8 neurectomy of the palmar digital nerve,
2 experimental thoracotomy, 1 laringeal protesis and 1 tenotomy), weaning was performed by a gradual reduction of the respiratory rate at the ventilator. Antagonism of the neuromuscular blockade was performed with the administration of neostigmine ${ }^{\mathrm{g}}$ $(0.02 \mathrm{mg} / \mathrm{kg}, \mathrm{IV})$ and atropine ${ }^{\mathrm{h}}(0.04 \mathrm{mg} / \mathrm{kg}, \mathrm{IV})$ after the recovery of TOF ratio to a value above 0.9 , as suggested by CULLEN (1996).

Lactated Ringer solution was given during the anaesthesia at a rate of $10 \mathrm{ml} / \mathrm{kg} / \mathrm{h}, \mathrm{IV}$, through a jugular venous catheter. The facial artery was cannulated for continuous pressure measurements (Biomonitor 6, BESE - Bio Engenharia de Sistemas e Equipamentos, Belo Horizonte, MG), continuous electrocardiogram (Biomonitor 6, BESE - Bio Engenharia de Sistemas e Equipamentos, Belo Horizonte, MG) as well as capnography (Multinex, Datascope, São Paulo, SP) were used for ventilatory and cardiovascular monitoring.

The hindlimb lateral digit extensor muscle was evaluated by placing the stimulating electrodes over the superficial peroneal nerve. Before placing the electrodes and the acceleration transducer, clipping and thoroughly cleaning of the skin were performed. Following anaesthesia stabilization, the TOF-Guard (Biometer, Organon Teknika, São Paulo, SP) was set up and the special mode activated because a five times amplification of the signal from the acceleration transducer was necessary. Next, an automatic start-up procedure was settled, which determines the level of supra-maximal stimulation required and sets the gain to achieve a control twitch height (T1) of $100 \%$. This was followed automatically by supramaximal TOF stimulation every 15 seconds. The monitor was allowed a period of 10 minutes for stabilization of baseline responses.

The time from injection of the muscle relaxant agent to the onset of maximum block (T1=0), recovery of $\mathrm{T} 1$ to $25 \%$ (clinical duration of action) and the recovery of TOF ratio to 0.7 (time of action) were recorded, as was the time for recovery of T1 from 25 to $75 \%$ (recovery index).

Mean and standard deviation were calculated for the pancuronium and the atracurium groups separately with the ANOVA test (variance analysis), and the test of t-Student for the comparison of the different time points within the two groups; $p<0.05$ was considered significant.

\section{RESULTS}

The average times to various end-points for the two drugs are given in Table 1 and 2. In the pancuronium group, 2 out of 5 horses did not reach a 
Table 1 -Values, means and standard deviation of the neuromuscular blocking monitoring in horses treated with pancuronium (Group 1) in different moments of evaluation.

\begin{tabular}{|c|c|c|c|c|c|c|c|}
\hline \multirow[t]{2}{*}{ MOMENTS } & \multicolumn{5}{|c|}{ HORSE } & \multirow[t]{2}{*}{ MEAN } & \multirow[t]{2}{*}{ SD } \\
\hline & 01 & 02 & $\mathbf{0 3}$ & 04 & 05 & & \\
\hline $\mathrm{T} 1=0(\mathrm{sec})$ & 140 & 181 & $-*$ & 287 & -* & 202.7 & 75.8 \\
\hline $\mathrm{T} 1=25 \%$ (min.) & 66 & 115 & 7 & 17 & $-* *$ & 51.25 & 49.7 \\
\hline T1 25-75\% (min.) & 14 & 46 & 15 & 10 & 35 & 24 & 15.7 \\
\hline $\mathrm{TOF}=0.7$ (min.) & 108 & 136 & 19 & 27 & $-* * *$ & 72.5 & 58.4 \\
\hline \multicolumn{8}{|c|}{$\begin{array}{l}\text { SD: standard deviation } \\
* \text { : did not reach a } \mathrm{T} 1=0 \\
* * \text { : did not decrease the } \mathrm{T} 1 \text { under } 25 \% \\
\text { ***: did not lower its TOF ratio below } 0.7\end{array}$} \\
\hline
\end{tabular}

T1=0 with the dosage used. In these cases the chronometer was settled to zero 5 minutes after the neuromuscular blocking agent administration, the same protocol was followed in the atracurium group.

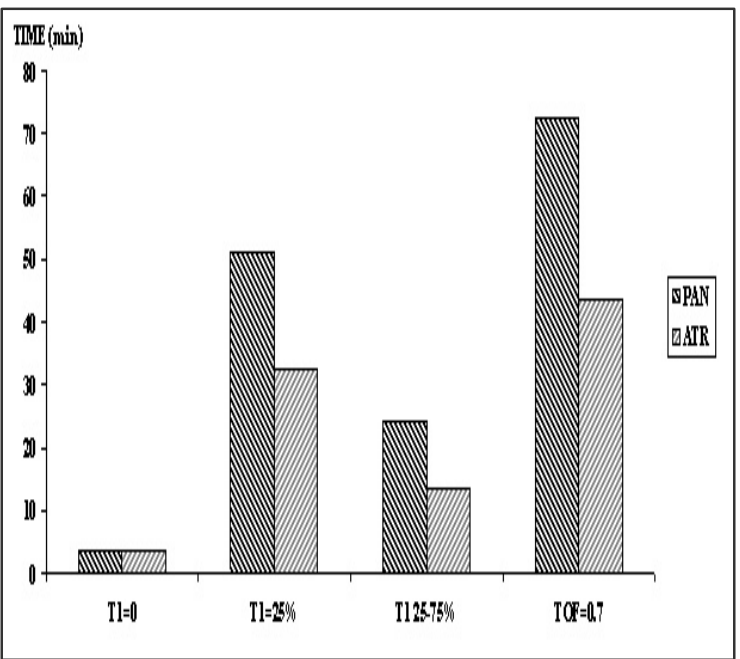

Figure 2 - Mean values of time for onset $(\mathrm{T} 1=0)$, clinical duration of action $(\mathrm{T} 1=25 \%)$, recovery index $(\mathrm{T} 1$ $25-75 \%)$ and action time (TOF=0.7) of the muscle relaxants pancuronium (5 animals) and atracurium (7 animals) given intravenously to horses.

The mean time for onset of the neuromuscular blockade was 3 minutes and 40 seconds for the pancuronium group and 3 minutes and 46 seconds for the atracurium group. In the atracurium group 3 out of 7 animals did not reach a T1=0. The time for onset of the neuromuscular blockade is demonstrated in Figure 2. The clinical duration of action $(\mathrm{T} 1=25 \%)$, time of action $(\mathrm{TOF}=0.7)$ and recovery index (T1 25-75\%) obtained with the use of pancuronium and atracurium in horses are demonstrated in Figure 2 and in Tables 1 and 2.

The mean values obtained at the different time points measured were not considered statistically significant when comparing the pancuronium with the atracurium group.

\section{DISCUSSION}

The TOF-Guard showed to be a valuable additional tool to veterinary anaesthesia; it is small, light and practical and easy to set up, reliable in use and did not require time for limb fixation. The TOF stimulation pattern was used continuously every 15 seconds during the neuromuscular blockade and the PTC was used in horses were T1 reached 0 . In all horses the amplification of the signal from the acceleration transducer was increased five times because of the lower acceleration signal obtained in horses probably due to the size and weight of the hind limb. This special mode is used in experiments with transducer placements other than on the thumb, the place proposed for transducer fixation in human medicine.

Time for onset $(\mathrm{T} 1=0)$, clinical duration of action $(\mathrm{T} 1=25 \%)$, recovery index ( $\mathrm{T} 125-75 \%)$ and the return of TOF to 0.7 , with a single dose of $0.1 \mathrm{mg} / \mathrm{kg}$ of pancuronium or atracurium had different individual values and mean values different from those established by KLEIN (1991) and CULLEN (1996) with the use of mechanomyography. Time for onset of neuromuscular blockade must be as short as possible since it is suggested that when administering a muscle relaxant agent to horses, controlled ventilation should start before administering these agents (KLEIN, 1991). In this aspect a short onset time agent is recommended. Pancuronium and atracurium with the dosage used had a long onset time.

Mean recovery index (T1 25-75\%) of pancuronium and atracurium was twice and four times respectively, when comparing to the values presented by CULLEN (1996) with the dosage of $82-140 \mu \mathrm{g} / \mathrm{kg}$ of pancuronium $(\mathrm{T} 1=50 \%)$ and 70 $85 \mu \mathrm{g} / \mathrm{kg}$ of atracurium $(\mathrm{T} 1=100 \%)$. The time points chosen for this study were established in recent human medical studies with muscle relaxants (JENSEN et al., 1993; HODGES, 1996; ANSERMINO, 1996; JAN et al., 1996; HANS et 
al., 1996; LLLWITZ et al., 1997; HANS et al., 1997). With the same single dose of pancuronium the horses had different responses, three out of five horses had a complete blockade and one did not block at all. Atracurium had more similar responses to the dosage used.

\section{CONCLUSIONS}

It is very important to monitor the neuromuscular transmission during the use of a nondepolarizing neuromuscular blocking agent, since there is a great variation between the individual responses to a same dose of these drugs neuromuscular blockade in children. Can J Anaesth, v. 43, n. 6, p. 589-594, 1996.

BOWEN, J.M. Monitoring neuromuscular function in intact animals. Am J Vet Res, v. 30, p. 857, 1969.

CULLEN, L.K. Muscle relaxants and neuromuscular block. In: THURMON, J.C., TRANQUILLI, W.J., BENSON, G.J. Lumb \& Jones' Veterinary Anesthesia. 3. ed. Baltimore: Williams \& Wilkins, 1996. Cap. 13. p. 337-364.

HANS, P., BRICHANT, J.F., FRANZEN, A., et al. Comparison of neuromuscular block of atracurium and rocuronium in adults. Acta Anaesthesiol Belg, v. 47, n. 2, p. 53-58, 1996.

HANS, P., BRICHANT, J.F., PIERON, F., et al. Elevated plasma alpha 1-acid glycoprotein levels: lack of connection to resistance to vecuronium blockade induced by anticonvulsant therapy. J. Neurosurg. Anesthesiol, v.9, n.1, p. 3-7, 1997.

HILDEBRAND, S.V., ARPIN, D. Neuromuscular and

Table 2 -Values, means and standard deviation of the neuromuscular blocking monitoring in horses treated with atracurium (Group 2) in different moments of evaluation.

\begin{tabular}{|c|c|c|c|c|c|c|c|c|c|}
\hline \multirow[t]{2}{*}{ MOMENTS } & \multicolumn{7}{|c|}{ HORSE } & \multirow[t]{2}{*}{ MEAN } & \multirow[t]{2}{*}{ SD } \\
\hline & 01 & 02 & 03 & 04 & 05 & 06 & 07 & & \\
\hline $\mathrm{T} 1=0$ (sec) & 169 & 169 & $-*$ & 240 & 252 & $-*$ & $-*$ & 207.5 & 44.7 \\
\hline $\mathrm{T} 1=25 \%$ (min.) & 28 & 27 & 40 & 49 & 41 & 24 & 18 & 32.4 & 11 \\
\hline T1 $25-75 \%$ (min.) & 12 & 11 & 16 & 15 & 17 & 16 & 6 & 13.3 & 3.9 \\
\hline $\mathrm{TOF}=0.7$ (min.) & 39 & 36 & 50 & 57 & 47 & 40 & 36 & 43.6 & 8 \\
\hline
\end{tabular}

and because this is the only way of knowing the level of blockade. The neuromuscular monitoring provides a safer anaesthetic and surgical procedure with the use of adequate dosages and the impossibility of a superficialization of the neuromuscular blockade during a surgical procedure. The TOF-Guard showed to be a good option for neuromuscular monitoring in horses and it is likely to improve considerably on tactile evaluation of the responses to stimulation.

\section{ACQUISITION SOURCES}

a - Sedivet ${ }^{\circledR}$, Boehringer de Angeli.

b - Valium ${ }^{\circledR}$, Roche Químicos e Farmacêuticos S.A.

c - Ketamina $50^{\circledR}$, Holliday - Scott S/A, Happyvet - Pharma, Comércio de Produtos Veterinários Ltda.

d - Halotano ${ }^{\circledR}$, Cristália - Produtos Químicos Farmacêuticos Ltda.

e - Tracrium ${ }^{\circledR}$, Laboratórios Wellcome - Zeneca Ltda.

f - Pavulon ${ }^{\circledR}$, Akzo Nobel Ltda - Divisão Organon.

g - Prostigmine ${ }^{\circledR}$, Roche Químicos e Farmacêuticos S.A.

h - Sulfato de Atropina ${ }^{\circledR}$, Laboratório Vigor.

\section{REFERENCES}

ANSERMINO, J.M., SANDERSON, P.M., BEVAN, J.C., et al Acceleromyography improves detection of residual cardiovascular effects of atracurium administered to healthy horses anesthetized with halothane. Am J Vet Res, v. 49, p. 1066, 1988.

HILDEBRAND, S.V., HILL, T., HOLLAND, M. The effect of the neuromuscular blocking activity of atracurium in halothane anaesthetized horses. J Vet Pharmacol Ther, v. 12, p. 277, 1989.

HODGES, U.M. Vecuronium infusion requirements in paediatric patients in intensive care units: the use of acceleromyography. Br J Anaesth, v. 76, n. 1, p. 23-28, 1996

JAN, G.S., TONG, W.N., CHAN, A.M., et al. Recovery from mivacurium block with or without anticholinesterase following continuous infusion in obstetric patients. Anaesth Intensive Care, v. 24, n. 5, p. 585-589, 1996.

JENSEN, E., LARSEN, S.W., SZTUK, F., et al. The TOFGuard: A new neuromuscular transmission analyzer. Anesthesiology, v. 79, p. A963, 1993.

JONES, R.S., PRENTICE, D.E. A technique for the investigation of the action of drugs on the neuromuscular junction in the intact horse. Br Vet J, v. 132, p. 226, 1976

KLEIN, L., HOPKINS, A.S., BECK, E., et al. Mechanical responses to peroneal nerve stimulation in halothane anesthetized horses in the abscence of neuromuscular blockade and during partial nondepolarizing blockade. Am J Vet Res, v. 44 , p. 781,1983 
KLEIN, L.V. Peripheral muscle relaxants. In: MUIR, W.W.; HUBBELL, J.A. Equine Anesthesia: Monitoring and Emergency Therapy. St. Louis: Mosby - Year Book, 1991. Cap 16. p 380-400.

LLLWITZ, E., ZUZAN, O., SCHULTZE-FLOREY, T., et al. Intubation conditions and the development of neuromuscular blockade with rocuronium in endoscopic ORL surgery. Anaesthesist, v. 46, n. 1, p. 14-20, 1997.

LOAN, P.B., PAXTON, L.D., MIRAKHUR, R.K., et al. The TOF-Guard neuromuscular transmission monitor (A comparison with the Myograph 2000). Anaesthesia, v. 50, p. 699-702, 1995

MANLEY, S.V., STEFFEY, E.P., HOWITT, G.A., et al. Cardiovascular and neuromuscular effects of pancuronium bromide in the pony. Am J Vet Res, v. 44, p. 1349, 1983.

MCCLUSKEY, A., MEAKIN, G., HOPKINSON, J.M., et al. A comparison of acceleromyography and mecanomyography for determination of dose-response curve of rocuronium in children. Anaesthesia, v. 52, n. 4, p. 345-349, 1997.
MELLONI, C. A new instrument for neuromuscular transmission monitoring: the accelerometer Tofguard. Comparative study of isometric force transduction in the assessment of pipecuronium dose-response relationship. Minerva Anestesiol, v. 61, n. 11, p. 471-482, 1995.

PEDERSEN, T., VIBY-MOGENSEN, J., BANG, U., et al. Does perioperative tactile evaluation of the train-of-four response influence the frequency of postoperative residual neuromuscular blockade? Anesthesiology, v. 73, p. 835-839, 1990.

SHORTEN, G.D., ALI, H.H., MERK, H. Perioperative neuromuscular monitoring and residual curarization. $\mathbf{B r} \mathbf{J}$ Anaesth, v. 68, p. 438, 1992.

UEDA, N., MASUDA, Y., MUTEKI, T., et al. A new neuromuscular transmission monitor (TOF Guard): the rationale behind the method and its clinical usefulness. Masui, v. 43, n. 1, p. 134-139, 1994.

Ciência Rural, v. 29, n. 1, 1999. 
Ciência Rural, v. 29, n. 1, 1999. 